\title{
Islamic Law and Terrorism in Indonesia
}

\author{
Ramlani Lina Sinaulan ${ }^{1}$ \\ ${ }^{1}$ Postgraduate Doctoral Program Jayabaya University, Jakarta, Indonesia \\ Email: linasinaulan@gmail.com
}

\begin{abstract}
:
Jihād and terrorism are not the same. In the context of sharia that implementation of the jihād has parameters measured with a layer of ethics based on the commands Al Quran and the Hadith of Prophet and the explanation the Ulama. Muslims in Indonesia views that the essentially not much different from the views on jihād and terror in other Islamic countries, especially the Middle East. In the context of Islamic law, jihād has multi spectral studies, but none of these studies that equate the meaning of jihād with terrorism, or none of them agreed that acts of terror as has been demonstrated by radical groups that are part of the concept Islam.
\end{abstract}

Keyword: Jihād, Islamic Law, Terorism, Indonesia, Radical Groups

\section{A. INTRODUCTION}

Terrorism as a crime against humanity and one of serious threat to the sovereignty of a country. Additionally, it can be categorized as a savage act, which is becoming a limelight of world community as an impact, particularly in the field of law. Terrorism that occurred in several countries shown the need for effort to prevent and solve the terrorism.

As background of born the terrorism is some of things such as politics and the problem of confidence or trust, which basically also comes from a sense of injustice. However, the embodiment or recovery on the matter pursued through the wrong way and even very dangerous for the public good. In addition, it is also influenced by the deviant actions that spawned an act of terror. In terms of politics can be seen when a person or group of people want to meet the political needs and interests, then it will justify any means to meet these needs, including acts of terror to the public in order to defeat and destroy his political opponents. From the foregoing, can be interfaced with the act of treason against the government are even more likely to spawned an act of terror.

Acts of terrorism that was born from a belief (religious) as an example can be seen irregularities from concept of jihād in Islam. So, any deviation actually from concept jihād in terms of fighting the infidels or other things that are contrary to the Qur'an and Sunnah. It is also based on their exaggeration attitude and extreme in understanding jihād regardless of rules or principles 'aqīda or correct understanding of the Qur'an and Sunnah.

Regardless of form or the background of birth, the act of terrorism shows us all that the act was in defiance. Terrorism said to be an act in defiance because it violates various rules of living in society which are contrary to the rules of religion, contrary to the values of humanity and others. It is in the eyes of the law is an act of disturbing the peace and security of society. 
Purposing of regarding nomenclature terrorism, according Muchamad Ali Syafa'at (2003:59) is notions, which argue that use of violent means and inflict fear is a legitimate way to achieve the goal. Thus, Nasir Abas (2012:1) argues that terror is a nasty reaction, which is seen as "lesser evil" by the perpetrators, so it is not the interactionism and can be grouped into hate crimes. Meanwhile, Dafrizal and Faridah Ibrahim (2010:36) defines "terrorism" as an act of violence that is not recognized by the government in which the action is done by a person or group of people who want to gain power and influence in society. In semantic-lexical, according Abdurrahman Pribadi and Abu Rayyan (2009: 9-10) terror mean chaos; abuses to cause chaos in society; acts of cruel and threatening.

Meanwhile, according fatwa Indonesian Ulama Council (MUI) No. 03 of 2004, that "terrorism is a crime against humanity and civilization which pose a serious threat to the nation sovereignty of dangers to world peace and security as well as detrimental to the welfare of society, terrorism is a crime which is organized both trans-national and classified extraordinary crimes, which do not distinguish targets ".

Understanding of terror literally can be cited from Webster's Dictionary who said that terror is a condition, mental condition was very scared, and anxiety is high. Thus, it can simply be said that terror is an act to create an atmosphere of fear that is very high for a person, or group, or community. In such conditions, the behavior of a person, group of people, who experience fear or anxiety is high, it can be manipulated to perform an action or activity were in accordance with the desire of the perpetrators of terror (Mangindaan, 2012: 1).

Term of terrorism is still relatively "new", especially in Indonesia. According Kacung Marijan, the word of terror is mentioned with term "system", régime de terreur that first appeared in 1789 in The Dictionnaire of the Academic Francaise (Marijan, 2003). The context of the French Revolution was attached to use that term. Therefore, the term terrorism when it has a positive connotation, the actions undertaken to overthrow tyrants and actions were successful. However, the practices of terrorism had long been going since around 66-67 BC, when a group extreme Jewish commit acts of terror, including murder, against the Romans who did the occupation in its territory (roughly in the disputed territory by Israel and the Palestinians now). Since then, acts of terrorism in various parts of the world, involving diverse ethnic and religious continue to occur (Mubarak, 2012: 241).

Since the events of September 2001 were shocked the world, in the United States, there was a tendency to reduce the notion of terrorism, which is identical with the religion of Islam. Every person who mentioned the word terrorist, then that is in our minds is the figure of Osama bin Laden or other "Muslim terrorists" (Sihbudi, 2007: 192). In fact, there are still a lot of a person or group of people who can be classified as "terrorist". The process of discrimination that eventually forms perspective to the movement of terrorists as radical Islamic movements.

In Indonesia, terrorism begins with the events in Bali had been twice shaken by a bomb which is an act of terrorists. The first bomb occurred on October 12, 2002 at Paddy's Pub and in front of the Sari Club, Legian, Bali. The incident is many caused no casualties, and most are victims are foreign nationals who come on holiday to Bali, meanwhile on October 10, 2005 occurred the second Bali bombings that caused many casualties and the most casualties is a citizen of Indonesia on holiday to Bali. Similarly happen at Makassar, known as Makassar bombing that occurred in a shopping center (MARI). Then occurred at Jakarta, which has occurred twice where is a major event, first is the bomb that exploded at the Marriott Hotel and the second is bombing in front of the Australian Embassy called the Kuningan bomb. In addition to that we mentioned above there are many acts of 
terrorism that has happened as a bomb exploded in Poso and Ambon. And the last is the suicide bombing that occurred in front of Sarinah Thamrin.

Related the incident, the Government of Indonesia reactively follow up with the authorized and enactment of Government Regulation in Lieu of Law (Government Regulation) No. 1 of 2002 on Combating Criminal Acts of Terrorism, which was later confirmed by Law No. 15 of 2003 on the establishment of Government Regulation in Lieu of Law No. 1 of 2002 on Combating Criminal Acts of Terrorism becomes law, and confirmed again by Law No. 16 of 2003 on the establishment of Government Regulation in Lieu of Law No. 2 of 2002 on the application of Government Regulation in Lieu of Law No. 1 Year 2002 on Combating Criminal Acts of Terrorism in the bombings in Bali on October 12, 2002 Date of becomes laws. In the progress of prevention and prosecution of terrorism, the Government together with the House of Representatives ratified and enacted Law No. 9 of 2013 on the Prevention and Combating Criminal Acts of Funding Terrorism, as a complement of Act No. 15 of 2003 , specifically relating to the financing of acts terrorism.

The other reactive action, because aroused controversy in their performance and funding, is the establishment of the Special Detachment (Densus) 88 through Presidential Instruction No. 4 of 2002 on Criminal Acts of Terrorism. Which is reinforced with the establishment of the National Agency for Combating Terrorism through Presidential Regulation No. 46 of 2010.

Regardless of the controversy Government actions in response to the terrorist group, the interesting thing is the development of understanding terrorism is always identified with one concept in Islam ie Jihād. Therefore, it becomes very important to put the term "terrorists" in its place. Although that is not an easy thing.

An internationally, there is a general agreement that the behavior of terror is a behavior which has been classified as an act which is contrary to humanity. However, whether one's actions are categorized as terrorism is not very easy. For example, United States, indeed look at Osama bin Laden was the "kingpin" of international terrorist groups. Then the question is whether people who have the same outlook and mindset against Osama bin Laden will be argued with the United States?

Not that different, when the Dutch colonial mentions of Prince Diponegoro or Captain Pattimura or Cut Nyak Dien, or those that existed at the time of colonialism struggle is being terrorists. Is it the same view of the Indonesian nation fighters with Dutch Colonial? The fact is that this time they are the ones who are considered a national hero. Thus, our understanding of the person or character in the recent past became important to find the parameters to the movement that is identical to the current period.

The understanding is the notion about the workings of human minds. Minds to form combinations and relationships of various kinds of events in the form of a pattern. However, despite these events often we understand in schematic form, our understanding may also arise due to freedom of thought, prejudices and language usage. Meanwhile, our own language is not free from the ebb and flow of history. Words or single statement has meaning assortment to the historical context in which the word or statement was pronounced. Similarly, to the historical understanding. The characters in history are not the only robot moved in accordance with the design. Historical figures are individuals who live, which shows the overall activities of sacrifice himself (Sumaryono, 1999: 58). By viewing and understanding the history of a character, we can admire or forgive mistakes. Historians make interpretations based on the data available, so none of the historian whose ideas completely objective. Every historian is always concern themselves with a particular place in space and time, also in busy life that he was influenced by the spirit contained within a certain time (zeitgeist). There 
is a possibility of a historian adheres to a particular ideology which he uses as a framework of thinking in the writing of history.

The attitude of the government toward radical movements during this time has been represented by linguist's expression through the art of writing from the Inspector General of Police Drs. Arsyad Mbai (2003: 128), in which there are motive behind the movement of terrorism in Indonesia, one of which is "Religious Ideology of Extremism", that confirms as follow:

"Motivation theory This is based on the attitude of religious radicalism is to build an exclusive community as capital and group identity vis a vis in the surrounding world that are considered decadent, a world of evil that must be destroyed. They believed himself the truest and closest to the doorway of God. Fight against them is a liability, while death is a take off towards home primordial (heavenly homes). Radicalism attitude like this that every time can give birth to social and political disaster. And this attitude also the underlying acts of violence they refer to as jihād bombings in Bali, Makassar, and various acts of terror such as bombings before Christmas 2000 and anarchic actions such as sweeping on American citizens, destruction of places of entertainment and so on. Indonesia as one of the largest Muslim countries their as such radical groups with motivations as described above."

Moving on from those views, indirectly, the Government of Indonesia cq Indonesian National Police has conducted stigmatization on groups allegedly and suspected of has committed acts of terrorism are criminal groups who use Islamic law as a basis paradigm.

According Komaruddin Hidayat that terrorism is happening in Indonesia, not only destroyed, but also enjoy a applied comprehensive (gestalt excitement) and the incredible euphoria to claimed the lives and devastating to many people. He said that terrorists deserve to be tried and sentenced to severe. No matter they (claimed to be) members of Jamaah Islamiyah or Jamaah Nasraniah. Komarudin Hidayat also said the group was misinterpret the meaning of jihād with qitāl (physical fighting). This indicates that terrorism as a splinter group. While Azyumardi Azra said that the real Islam Indonesia is general does not differ from Islam in the Middle East. However, since the tragedy of September 2001 this perception suddenly changed. Islam in Indonesia subsequently blamed as the headquarters of the terrorists. Too soon for us to justify this statement. However, movement the Indonesian Islamic radicalism is an indisputable phenomenon. Furthermore, according Suherman that the phenomenon was not a new thing, since long before this, such as Padri movement, has appeared similar movements. But he argued, that of all the characters from those movements, the Indonesia radicalism is more politically motivated than religion (Suherman, 2008: 72-73).

The interesting thing is the shooting incident and bombing in Sarinah dated January 14, 2016. Behind commotion terror acts concern to the Indonesian people, and even the attention of the international community, has been exploited by the Minister Sudirman Said in order to make the process of signing a contract extension with PT. Freeport. Several times when terrorist acts and explosions in the Postal Police (police station) and a Starbucks cafe on the street MH Thamrin, Central Jakarta successfully suppressed, however the speculation and conspiracy theories have sprung up. The speculation that most powerful blows was acts of terror intended to cover the major issues. In the midst of public attention throughout Indonesia who sucked on Sarinah and surrounding regions, the Minister of Energy and Mineral Resources (ESDM) Sudirman Said was accused of presumptuous represent Indonesia to allow the extension of the contract of PT Freeport (www.rimanews.com). So, that political motives is behind the terrorist acts was sometimes becomes a tool for the Government of Indonesia to avoid the public spotlight. 
In outline, the purpose from acts of terror can be divided into four broad categories, namely; (1) Irrational terror, is the terror acts committed by persons or groups for the purpose of personal interest, to satisfy the desires of unilateral, or - other actions that do not make sense. (2) Criminal terror, is an act done by a person or group whose purpose (crime) for the benefit of their group, for example the Yakuza, the Mafia, Organizatia. Groups or particular religious sect may be included in this category.(3) State (sponsored) terrorist the terror acts committed by the authorities of a country to his people, whose goal is forming behavior for entire society as a wish of ruler, or addressed to the state or other parties.(4) Political terror, is a terror activities carried out by certain groups or networks aimed at political (Mangindaan, 2012: 2).Based on the classification, terrorism is comes from "splinter" Islamic groups - in the nomenclature from Komarudin Hidayat - can be classified into the group of criminal or political terror.

A classifying, the intrinsically is crystallization of standing point the researchers in giving that definition. Issue for the standing point or horizon point from viewpoint someone was became important to find the scientific truth on his views.

According Jaih Mubarak (2012: 242-243) that idea of how terrorism is defined, there are four different groups of views on terrorism, namely (1). Academics, (2). Government, (3). The general public, and (4). The terrorists and their supporters. In general, academics promoting intellect and remain neutral in conducting research on everything about terrorists. Academic culture, such as curiosity, skepticism, and a set of methodologies will be able to bring the attitude and discoveries of meaning a more independent and non-partisans than other groups. The definition of terrorism of this group emerged in 1988, which states that terrorism is a method inspired by the desire to do acts of violence repeatedly, carried out by individuals, groups, or the ruler of underground (clandestine), for reasons of idiosyncratic, criminal or political. Therefore, in contrast to assassination, which is directly executes the target of assassination, whereas the direct targets violence of terror is not the persons who became main target. The victims of violence are usually chosen randomly (targets of opportunity) or selected (representative or symbolic targets) from citizens who became the target, which is then used as the source of the message. Threats and violence-based communication processes between terrorist and the victim used to manipulate main target actually. This last target is the target of terror, demands, or attention, depending on the level of intimidation, coercion and propaganda desired.

The definition was used by the authorities that tended to interpret the term terrorism is more extreme, as they are obliged to actively combat terrorist activities, and even become a victim of terrorism. The British government was the first to formulate the official definition to distinguish between terrorist and criminal acts. In 1974, it was explained that the definition of "terrorism is the use of violence for political purposes, and including the use of violence to make the people in fear." In 1980, the CIA (Central Intelligence Agency) defines terrorism is the same as "the threat or use of violence for political purposes by individuals or groups, on behalf of or against the legal government, to scare the public broader than the direct victims of terrorist", While the terrorist groups have a different view of other observers. While at the end of the 19th century has many bomb throwers from Russian anarchists and socialists do not feel discouraged labeled as terrorists, but it is not the case with contemporary terrorists. Those latter called conscious about stigma calling of terrorists and therefore seeks to avoid the label of terrorists. At the time, have been organized a conference on terrorism in Leiden in 1989, a group calling itself the Revolutionary Commando Marinus van de Lubbe, sent a letter to the local newspaper to declare his sympathy to the people who claimed as downtrodden like: Palestine, Ireland, Central America, and Kurdistan. They said: "it is clear that the so-called terrorism is actually a logical and fair resistance from people against terrorism the government, capitalism, racism, and imperialism." 
Giovanna Borra Dori in Philosophy in a Time of Terror [2005], cited by Jaih Mubarok (2010: 47) provides a reinterpretation more deeply and critically to various global phenomena, in particular is so called terrorism. Furthermore, that the term of terrorism is a pragmatic interpretation, which many veiled therein various interests, whether economic, political, cultural, and others. Jürgen Habermas [2001] also assessed, the interpretation of terrorism that developed during is so unilaterally. Fundamentalism as the main group responsible for the September 11th so massively exposed by the Western media, so that any community-related and touch even "equal in formal attire" was claimed as part of the current fundamentalism. For Jürgen Habermas that fundamentalism is very political. In Islam particularly, the current of fundamentalism has been politicized by certain persons to play a political interest as unilaterally. Thus, truth claims are often carried fundamentalists, not just blame the Muslims who disagree with an sich, but the more tragic is blaming the other religions who are considered undermine his religion.

Based on the foregoing, it becomes important for us to get into the growing understanding of Islamic law in Indonesia on the development of terrorist acts that are believed by the Government of Indonesia as part of radical groups based understanding of Islam.

As limitation on this study, the author proposes the formulation of the problem, which is a limitation of issues to be studied, as follows:

"How does the perception of Islamic law that growing and developing in Indonesia against acts of terror committed by radical groups on Indonesian society?"

\section{B. METHODS}

This study is a normative legal research, the research to obtain the necessary data with respect to the problem. The study used secondary data consists of primary legal materials, secondary law and tertiary legal materials. In addition it also used primary data such as interviews as supporting secondary data. To analyze the juridical analysis was conducted using qualitative method.

\section{RESULT AND DISCUSSIONS}

In the discourse of Islam, according Mubarak Zulfi (2012: 245), many people associate an ideology of terrorism with the doctrine of jihād, which in Christianity is equated with the crusade. There are 41 times - according Quraish Shihab - says jihād is mentioned in the Qur'an. In the tradition of Islam, jihād has a variety of meanings. However, an outline of jihād is divided into two concepts: Firstly, moral concept is defined as the struggle of Muslims against lust or struggle against itself (jihād alnafs), which is called the al-jihād al-akbar. Secondly, the political concept, defined by the concept of "just war," al-jihād al-așghar. According Bonney, the two concepts side by side these always changing and growing all the time. Thirdly, at the beginning of Islam when the boundary territories of dominion had not existed on the Islamic, and jihād is defined as a concept of war. However, the meaning of jihād has changed when the Islamic government stood up and had delimited territory. The next process, the Islamic world is recognized and in fact lives in harmony with the neighboring countries that are not Muslims. Bonney confirms that the use of the concept of jihād in early of Islam to define the meaning of "war" in the modern era Islam is an anachronistic, as well as damaging the reputation of Islam.

According to the concept of Islamic law, any act containing the violence and bring damage without based on the grounds that sharia was prohibited, even Allah SWT threatens to anyone who did and 
make acts that resulted in the emergence of mischief in the earth, as the word of Allah SWT in the Qur'an Surah Al-Maida verse 33 asserts as follows:

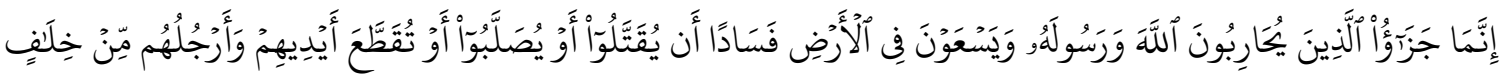

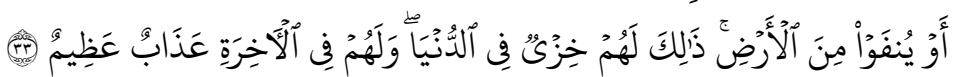

"Indeed, the penalty for those who wage war against Allah and His Messenger and strive upon earth [to cause] corruption is none but that they be killed or crucified or that their hands and feet be cut off from opposite sides or that they be exiled from the land. That is for them a disgrace in this world; and for them in the Hereafter is a great punishment,"

However, according Saidurrahman (2012: 55) that a problem encountered in matters of terrorism is the actors in various bombings in Indonesia, even in this world, Islamic organizations fundamentally in the various regions in Indonesia, which states that their actions are jihād in the way of Allah. According to them, the Muslims in the world has been suppressed by the act of a superpower and its allies. They claim that jihād is not only because of religious motives alone, but jihād by means of war can also be done to escape the oppression of certain parties as well as maintaining security and stability of the country.

The word of Jihād, in view of Hamka (1970: 290) is a refinement of all worship, thus, the meaning of jihād is a pole of worship as the embodiment love of Allah in which a servant willing to give up their body and soul and his property for the struggle. Meanwhile, according to Quraish Shihab, very diverse forms of the word jihād in the Qur'an. The word jihād is picked up from the word "jahd" which means "tired/difficult". The Jihād is difficult and causes fatigue. Some think that jihād is derived from the root word "juhd" which means "ability". This is because jihād requires the ability, and should be done as big as ability. From the same word are composed the utterance "jahidah bi al-rajul" which means "a person is undergoing test". Seen that word implies the trials and tribulations, a natural thing because jihād is a test and trial for quality of a person.

Referring to Al-Qur'an Surah Ali-Imran verse 142 which asserts "Do you think that you will enter Paradise while Allah has not yet made evident those of you who fight in His cause and made evident those who are steadfast?" Therefore, jihād is one mechanism of exam set for man to attain the end goal is heaven, through an instrument called the "patient".

Furthermore, Quraish Shihab (1996: 502) explains the word of "jihād" which is contains the meaning of "ability" which demanded the fighters put out all the power and ability to achieve objectives. Therefore, the word jihād is sacrifice, and thus the mujahid not demand or take, but to give everything he had. When giving, he does not stop until the goal is reached or it has expired. Said Aqil Siraj (2006: 106) says that, the theme of jihād itself is derived from the word "jahada", means the business or undertaking. Derivations, jahada, yajhadu, jihād, and mujāhada. So, talking about jihād also means talking about its derivation or musytaqqāt, namely ijtihād and mujāhada comes from a root word meaning seriousness and sincerity.

Meanwhile, according to Saidurrahman, (2012: 57) that jihād in the meaning of sharia have the sense of general and specific. A general understanding was devoting all ability and sincerity in obedience to Allah SWT. In this understanding of jihād has a broad scope and general nature, including passions, politics, oral, worship, science, propaganda, and so on. While a special jihād is a holy war in the cause of Allah, as referred to in verse from the Qur'an that talk about the jihād. As for the meaning of shar'i (Sharia), the fuqaha defines jihād as an effort to mobilize all forces in the 
war fĩ sabilillāh directly or give financial assistance, opinions, or logistic support, and others (to win the battle). Therefore, the war in order to elevate the word of Allah is what is called jihād.

However, jihād in the sense of qitāl (at war), the concept of Islamic law has also been set its ethics, which in particular must be applied with reference to rahmatan lī al-'ālamīn of Islamic teachings, then in warfare is forbidden to kill children, women frail, elderly of helpless, unarmed civilians, destroying places of worship, even should not interfere with livestock.

As affirmed of statement Hizbut-Tahrir Indonesia Centre No. 86/PU/E/12/05 dated December 18, 2005 which confirmed that Jihād in Islam means the physical war was carried on the battlefield (qitāl), and face to face with the enemy, have laws, rules, and noble character, among others, should not kill children, women, old people, damaging houses, houses of worship, and including trees. Hizbut-Tahrir Indonesia Centre also asserted that jihād it should be done in accordance with the rules of Islam and amr ma'rüf nahy munkar, Islam never teaches the violence that is not directional which is impact on hatred.

Opinions mentioned was based on Al-Quran Surah Ali Imran verse 110 which asserts as follows:

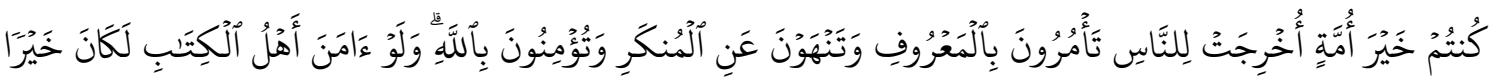

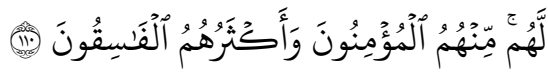

"You are the best nation produced [as an example] for mankind. You enjoin what is right and forbid what is wrong and believe in Allah. If only the People of the Scripture had believed, it would have been better for them. Among them are believers, but most of them are defiantly disobedient."

According to Ahmad al-Maraghi Musthofa (1987: 44), the meaning of that verse was about to explain why the phrase "amr ma'rūf nahy munkar" the mention of word it was precedence in the appeal of faith in God, whereas faith is always in front of various types of obedience. This is because amr ma'rüf nahy munkar is a door of faith and who nurture it. Thereby, these two things to take precedence over the narrative in the customs that occurs among mankind that is makes a door be located in front of everything. Based on this interpretation, the grammar in the context of Indonesia's all it can be interpreted that the actions of "enjoining good and forbidding wrong" must first be based on "faith in Allah SWT", which aims to be the people best. In the context of the faith, the appreciation and practice and understanding must be wrapped in the fabric of the Five Pillars of Faith. Where obliging to every Muslim in addition to thinking dogmatically, also think in terms of ethics that follows the dogma that.

As affirmed in the Qur'an Surah al-A'raf verse 157 which asserts as follows:

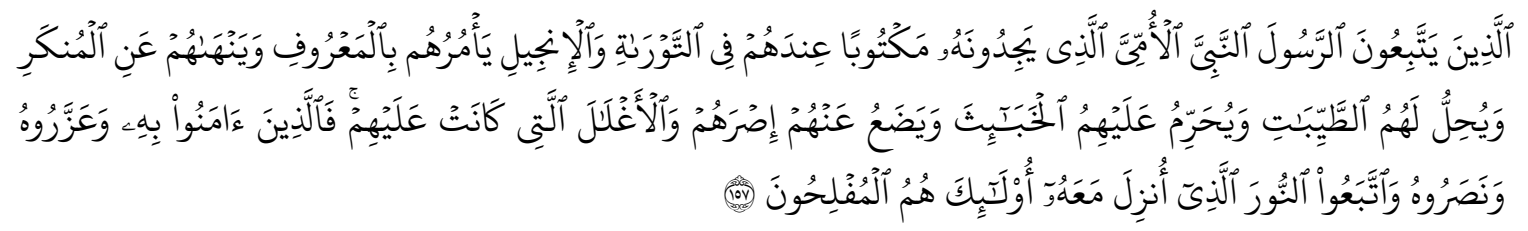

"Those who follow the Messenger, the unlettered prophet, whom they find written in what they have of the Torah and the Gospel, who enjoins upon them what is right and forbids them what is wrong and makes lawful for them the good things and prohibits for them the evil and relieves them of their burden and the shackles which were upon them. So, they who have believed in him, honored him, 
supported him and followed the light which was sent down with him - it is those who will be the successful."

Ahmad Musthofa al-Maraghi (1987: 148) explains the meaning of above verse that unlettered of Prophet just told the fine and does not prohibit except the bad, as the word Abdullah bin Mas'ud, "if you hear word of Allah, yā ayyu ha al-ladhina āmanū, then hearken to hear, because the word (which is preceded by, yā ayyu ha al-ladhina āmanū, that explanation contains good things you have told to do so, or the ugliness that forbidden)".

Thus, the implementation from jihād itself apart was based to the faith in Allah SWT, also was based how to the way Prophet and his companions do so.

In Islam, jihād has a strong foundation which is al-Qur'an and hadith which later socialized that has been exemplified by the Prophet and his companions. Therefore, in Islam when judging from the standpoint of Islamic law and history, theory and applications will be very much different between jihād with the terrorism. The difference is like heaven and earth. Terrorism does not distinguish what is right and what is falsehood. The culprit always feels thirsty with the violence and blood, so when the victims fell then later they were satisfied, and of course such behavior is condemned by Islam (Arake, 2012: 190).

About jihād, which some people interpreted as jihād qitāl (war), then it must know in advance the level of concept jihād in Islam. As confirmed by Ibn Qayyim al-Jawziyyah (1994: 9) that classifies jihād into four parts, namely:

1. Jihäd in the face of lust.

2. Jihād in the face of devils.

3. Jihād in the face of the infidels and hypocrites

4. Jihād in the face of arbitrariness, injustice, and wickedness.

Understanding of jihād in the context of qitāl (war), essentially has been affirmed in the Qur'an Surah Al-Hajj verses 39-40, which asserts as follows:

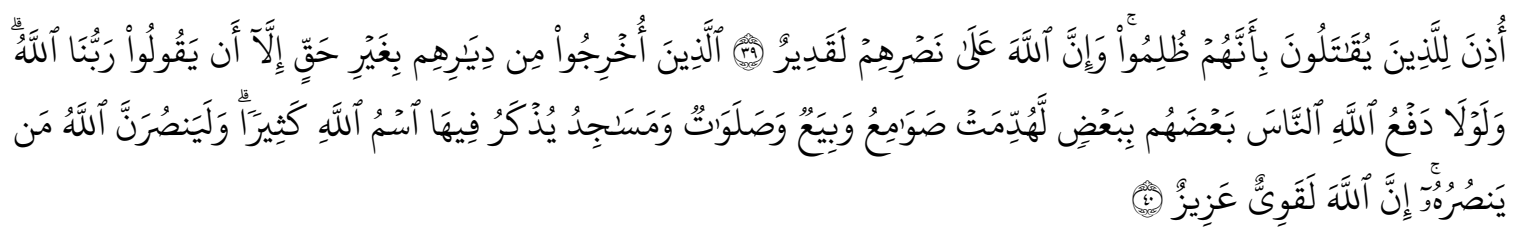

"Permission [to fight] has been given to those who are being fought, because they were wronged. And indeed, Allah is competent to give them victory. [They are] those who have been evicted from their homes without right - only because they say, "Our Lord is Allah." And were it not that Allah checks the people, some by means of others, there would have been demolished monasteries, churches, synagogues, and mosques in which the name of Allah is much mentioned. And Allah will surely support those who support Him. Indeed, Allah is Powerful and Exalted in Might."

Based on the verse, then the parameters and ethics in jihād-qitāl as follows:

a. Only permitted for the people who combated beforehand, with the reasons have been persecuted namely people who were evicted by the unauthorized means;

b. Qitāl intrinsically passive; 

c. Prohibited to perform malignancy;
d. Prohibited from destroy houses of worship, monasteries, and churches.

In the context of Qitāl, then the concept of understanding is not as simple as interpreted by the radical groups. Qitäl or war should be based on consideration for the commands of Allah and His Prophet. As affirmed in the Qur'an Surat Al-Baqara verse 216, as follows:

"Fighting has been enjoined upon you while it is hateful to you. But perhaps you hate a thing and it is good for you; and perhaps you love a thing and it is bad for you. And Allah Knows, while you know not."

The new Qitäl will become active when a person is able to interpret the permission granted by the Allah SWT. However, through a systematic interpretation, confirmed also in the Quran Surat AlBaqara verse 208 which confirms "O you who have believed, enter into Islam completely [and perfectly] and do not follow the footsteps of Satan. Indeed, he is to you a clear enemy.". Were subsequently spliced with the Al-Qur'an Surah Al-Nisa verse 90 which asserts as follows:

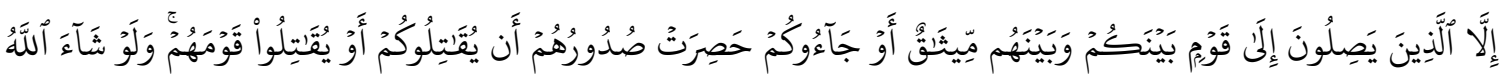

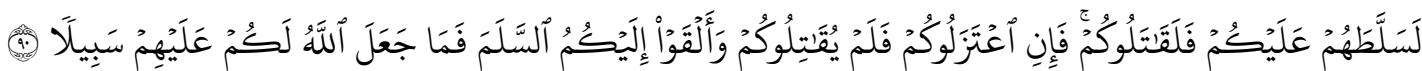

"Except for those who take refuge with a people between yourselves and whom is a treaty or those who come to you, their hearts strained at [the prospect of] fighting you or fighting their own people. And if Allah had willed, He could have given them power over you, and they would have fought you. So, if they remove themselves from you and do not fight you and offer you peace, then Allah has not made for you a cause [for fighting] against them."

Based on these provisions, according to 'Abd al-Wahab Khallaf (1988: 56) that jumhur (majority opinion) of the scholars have argued that basic relationship between Muslims with non-Muslims is peace and not war. Therefore, it is not wrong when Yusuf al-Qaradawi (1989: 74) explains that jihād is a Muslim obligation that continues until the Day of Resurrection; the lowest level of a refusal of the above vices or kemungkaran and the highest form of roads in the way of Allah. Among them is the struggle with the verbal, pen, hand in the form of a statement of truth in front of authorities' wrongdoers.

According to Abdul Aziz (2004: 127) that Allah SWT has obliged Muslims to fight in the way Allah swt. But warfare is limited to those who attacked the Muslims only. While those who do not fight the Muslim, be left not for combated. As affirmed in the Qur'an Surah Al-Baqara verse 190, as follows:

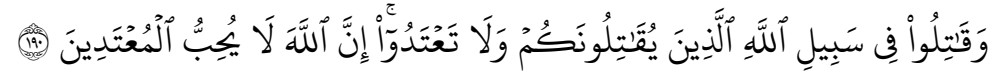

"Fight in the way of Allah those who fight you but do not transgress. Indeed. Allah does not like transgressors."

At the next stage in the context of jihād, in the Qur'an indeed there a command to do Qitäl, but in terms of the war, explicitly Al-Quran imposes limits is "not transgressors". As for the second limitation that contained in the Qur'an Surah Al-Baqara verse 192, which asserts as follows:

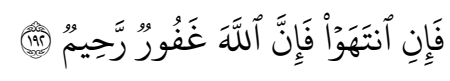


"And if they cease, then indeed, Allah is Forgiving and Merciful."

A third limitation, contained in the Quran Surah Al-Baqara verse 193 which asserts as follows:

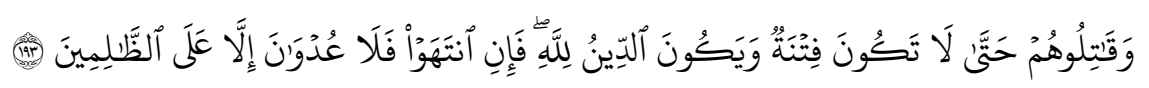

"Fight them until there is no [more] fitnah and [until] worship is [acknowledged to be] for Allah. But if they cease, then there is to be no aggression except against the oppressors."

Thus, in addition to the first limitation that should not extend beyond the limit, then the second limitation is stop when Muslims are no longer oppressed. And third limitation is Qitāl should only be done to muffle defamation.

The problem is that the proposition or argument from radical Islamic groups are using the Qur'an Surah Al-Baqara verse 191, which asserts as follows:

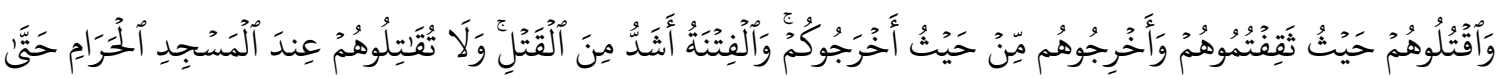

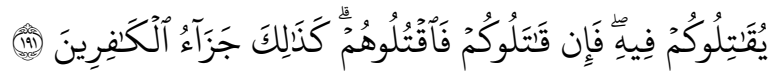

"And kill them wherever you overtake them and expel them from wherever they have expelled you, and fitnah is worse than killing. And do not fight them at al-Masjid al- Haram until they fight you there. But if they fight you, then kill them. Such is the recompense of the disbelievers."

An understanding that's not comprehensive from the Qur'an Surah Al-Baqara verse 191 raises a distorted interpretation. The understanding of text was not equipped with the knowledge of texts of the Qur'an others. Understanding of text Qur'an must be understood with systematic of coherence. Moving on from the meaning of "text" itself as a braid or a circuit. In other words, the text of Qur'an from surah Al-Baqara verse 191 that does not stand alone.

How to perform the interpretation of the third verses? With using the method of Hans-George Gadamer in interpretation explains that a relationship prevalent we are with the past is not characterized with realignment and liberation of ourselves from tradition, but we are always look at the situation in that traditions, and this is not a process that objectivation - meaning we do not understand what the tradition as something else, something unfamiliar. The tradition has always been a part of us, a model of recognition of ourselves will later historical assessment can hardly see it as a kind of knowledge, but as a most sincere bond with tradition (Hardiman, 2014: 4). If so, the tradition, as well as the authorities, is the condition for understanding. Then we can talk about prejudice legitimate if it is related to authority and tradition that encourages the discovery of truth. Hans-Georg Gadamer in Truth and Method, shows that in the social sciences-human, even in the natural sciences, there is a tradition of research that is refer towards discoveries in these sciences. Elements of this tradition, as illustrated Gadamer, "active" of work which means had a significant effect in these sciences research. There is no understanding that working alone, which means without prejudice, because for every understanding, not least in the modern sciences, "work" is elements of authority and tradition. Gadamer attempts to rehabilitate authority and tradition implications on the notion of historical consciousness (historisches Bewußtsein). Understanding the history of not only means that we understand the historical phenomena, such as understanding the contents of the works of the past, but also to understand the effect of these works in history (Hardiman, 2014: 5). 
Based on that, Bernard Arief Sidharta (2013: 34) explains that every person (subject to interpretation or interpretator) born (meaning: thrown, geworfen) into the world history product that is always undergoing a process historically continuous, which is tradition-laden values, insights, understandings, principles, meanings, rules, behavior patterns, and so on, are formed and evolve in the course of history. Thus, each subject, irrespective and independent of his will, always finds itself already in a tradition that existed before it was born. Through the process of interaction with the world around, the process of making himself or the educational process in the broad sense (bildung), and with the form of prejudice or pre-understanding (vorverstandnis) to everything. Thus, forming a horizon containing all things that seemed from a point of view certain subjective.

Based on the foregoing, it can be concluded that an interpreter, so essentially already have subjective views as an initial understanding or preunderstanding or preconceptions. However, it cannot be used as a basis as the establishment of a decision.

According to E. Sumaryono (1999: 83) that use of initial understanding or preunderstanding or preconceptions to be able to understand a text, should be throw away all forms of pre-conception with the intention that the interpreter becomes open to what is said by a text. Instead, the interpreter anticipates and interpret according to what we would have (vorhabe), what we saw (Vorsicht), as well as what we will get later (vorgriff). So, instead of the consideration that we had before, which by Hans-Georg Gadamer considered negative or low.

Based on that, knowledge of the traditions and knowledge (bildung) the texts of the Qur'an become very crucial in reaching a conclusion. In the context of Islamic law, the tradition known as asbāb alnuzūl (causes of the decline in verses of the Qur'an).

Tracking through the traditions contained in asbāb al-nuzūl, it is known that Al-Qur'an Surah AlBaqara verse 190-193 are verses revealed at the same time of an event after the Treaty of Hudaybiyyah.

In Tafsir Ibn Kathir, the author have been interpreting with describe very long, He explained that the verse down in Treaty of Hudaybiyyah. That is, when the Prophet was prevented to go to Baitul Haram, then he was invited come to terms by the idolaters to return next year. When the next year, he and his companions get ready to perform Umrah "qadha". However, their worry when the Quraysh is not fulfilling their promise and deter them again to enter the Baitul Haram, as well as the fight against them, while the friends are not pleased to do battle with the idolaters in the sacred months. So, Allah revealed His word verses 190 of surah al-Baqara (Al-Sheikh, 2004: 365-368).

This verse is the verses of madaniya for the first time allow Muslims to retaliate attack from the idolaters, when the Muslims under attack suddenly, though the attack occurred in the forbidden months, namely Rajab, Zulkaidah, Zulhijjah and Muharam, as described in verses ago. In an age of ignorance, these months are considered month prohibition for battle. The prohibition recognized by Islamic, however due to the Pagans break first, then Allah allowed the Muslims returned their attack. Before hijra, there is no verses that allows the Muslims to attack in retaliation. Among the interpreters there is no disagreement that the battle was forbidden in Islam in those days.

\section{CONCLUSION}

Based on the foregoing, the meaning of jihād is not the same as terrorism. Implementation of jihād in the context of Syariah parameters measured with ethics based on commands of the Qur'an and the Hadith of the Prophet and individual interpretation of scholars. The views of Muslims in Indonesia 
are essentially not much different from the views on jihād and terror in other Islamic countries, especially the Middle East.

Jihād in the context of Islamic law, has a multi-spectral study, but none of these studies that equate the meaning of jihād with terrorism, or none of them agreed that acts of terror as has been demonstrated by radical groups, is part of the concept Islam.

The developments of terrorist acts that have occurred are still not showing its form as a valid act. The development of terrorist acts in Indonesia are not always purely for religious motives as political stage, likewise the acts of terror in Sarinah is one of exclusion, which in general by the Indonesian people will not be considered as a form of terrorism. 


\section{References}

Abas, Nasir. (16 Januari 2012). Kajian tentang Terorisme, Makalah disampaikan pada Diskusi Kajian tantang Terorisme di Ditjenstarahan Kementerian Pertahanan Republik Indonesia.

al-Jawziyyah, Ibn Qayyim. (1994). Z d al-Ma‘ā d, Jilid 3, Bayrūt: Mu'assasah al-Risālah.

al-Maraghi, Ahmad Musthofa. (1987). TarjamahTafsir al-Maraghi, Semarang: CV. Toha Putra.

al-Qardhawi, Yusuf. (1989). Pendidikan Islam dan Madrasah Hasan al-Banna, [Pent. Bustami A. Ganidan Zainal Abidin Ahmad], Jakarta: Bulan Bintang.

Al-Sheikh, Abdullah bin Muhammadi bin Abdurrahman bin Ishaq. (2004). Tafsir Ibnu Katsir. Jilid 1, [Pent: M. Abdul], Bogor: Pustaka Imam Asy-Syafi' i.

Arake, Lukman. (2012). Pendekatan Hukum Islam Terhadap Jihād dan Terorisme, Ulumuna Jurnal Studi Keislaman, Vol. 16 (1).

Aziz, Abdul. (2004). Imam Samudra Aku Melawan Teroris, Solo: Jazera.

Dafrizal and Faridah Ibrahim. (2010). Pembingkaian Metafora dan Isu Terorisme: Satu Interpretasi Konseptual, Jurnal CoverAge, Vol.1, No.1, September 2010.

Hamka. (1970). Falsafah Hidup, Jakarta: Jaya Murni.

Hardiman, F. Budi. (25 Februari 2014). Gadamer dan Hermeneutika Filosofis, Makalah untuk kuliah terakhir Kelas Filsafat Seni Memahami: Hermeneutika dari Schleiermacher sampai Gadamer, Serambi Salihara.

Khallāf, 'Abd al-Wahab. (1988). Al-Siyāsah al-Shar'iyyah, Kairo: Dār al-Qalām.

Mangindaan, Robert. (November 2012). Terorisme dan Gerakan Radikal di Era Globalisasi, Jurnal Quarter Deck, FKPM, Vol. 5, No. 17.

Mbai, Arsyad. (13-14 Oktober 2003). Terorisme dan Penanggulangannya, Makalah disampaikan pada Seminar tentang Penegakan Hukum Terhadap Terorisme, diselenggarakan oleh BPHN Departernen Kehakiman dan HAM bekerjasama dengan Fakultas Hukum Universitas Padjadjaran, Bandung.

Mubarak, Zulfi. (2012). Fenomena Terorisme di Indonesia: Kajian Aspek Teologi, Ideologi dan Gerakan, Volume 15 (2).

Mubarok. (2010). Stigmatisasi Pemberitaan Terorisme di Media Massa, Semarang: Pascasarsajana Magister Ilmu Komunikasi.

Pribadi, Abdurrahman and Rayyan, Abu. (2009). Membongkar Jaringan Teroris, Jakarta: Abdika.

Saidurrahman. (2012). Fiqh Jihād dan Terorisme (Perspektif Tokoh Ormas Islam Sumatera Utara), Jurnal IImu Syariáh dan Hukum, Vol. 46 (1). 
Shihab, M. Quraish. (1996). Wawasan Al-Quran, Tafsir Maudhui Atas Pelbagai Persoalan Umat, Bandung: Mizan.

Sidharta, Bernard Arief. (2013). IImu Hukum Indonesia. Upaya Pengembangan Ilmu Hukum Yang Sistenatik Yang Responsif Terhadap Perubahan Masyarakat, Yogyakarta: Genta Publishing.

Sihbudi, Riza. (2007). Menyadera Timur Tengah. Ketidakbijakan AS dan Israel Atas Negara-Negara Muslim, Jakarta: Mizan.

Siroj, Said Aqil. (2006). Tasawuf Sebagai Kritik Sosial, Bandung: Mizan dan Yayasan Khas.

Suherman, Iwan. (2008). Tinjauan Hukum Islam Terhadap Aksi Terorisme Di Indonesia (Analisis Fatwa MUI Np. 3 Tahun 2004 Tentang Terorisme), Jakarta: FH UIN.

Sumaryono, E. (1999). Hermeneutik. Sebuah Metode Filsafat, Yogyakarta: Kanisius.

Syafa'at, Muchamad Ali. (2003). Tindak Pidana Teror Belenggu Baru bagi Kebebasan dalam "terrorism, definisi, aksi dan regulasi", Jakarta: Imparsial.

"Teror Bom Thamrin dan Perpanjangan Kontrak Freeport, Ada Apa?". (accessed 4 Februari 2016). Source: http://rimanews.com/nasional/politik/read/20160116/256051/Teror-Bom-Thamrindan-Perpanjangan-Kontrak-Freeport-Ada-Apa- 
Islamic Law and Terrorism in Indonesia 